\title{
Mississippi subsides, leaving research debate in its wake
}

Washington. As the great Mississippi floods subside, hydrologists are looking to greater research and stronger models to better manage the nation's flood plains.

Conservation groups have attacked the Clinton Administration for failing to coordinate the various agencies that are looking at what now should be done. The 15,000strong American Rivers group, which is worried that flood control levees on the

just the first instalment. Meanwhile, reports by eminent persons on how to manage river basins better have been gathering dust.

"You've got to take the opportunity to change the system", says Eugene Stakhiv, chief of policy at the Corps of Engineers' Institute of Water Resources at Fort Belvoir, Virginia. The Corps has had a long and frantic summer. It built the physical flood control barriers on the upper Mississippi,

and has been subject to considerable criticism, much of it ill-informed. It is keeping an open mind on how to respond to the floods, according to Stakhiv.

Stakhiv, who attended Ragone's panel meeting, says the main conflict is between scientists who want to gather data to build reliable hydrological models in the longer term, and those who want data to make decisions on such urgent matters as whether to reconstruct levees on the Mississippi.

What is most important is that the various agencies should agree upon a strategy. "Let's assume we get $\$ 100$ over flooded terrain, reveal the extent of flooding near the Mississippi-Missouri-Illinois confluence, 2 August 1993.

Mississippi will simply be rebuilt, has called on Clinton to set up a panel to review not only flood control on the Mississippi but also national flood control policies. "There is no-one in charge of US flood control", complains its director, Kevin Coyle. "Nothing is happening," says Beth Norcross, legislative director of American Rivers. "It is sitting in the White House's lap."

But scientists from the various agencies are already coordinating their activities both officially and informally. The Federal Coordinating Council for Science, Engineering and Technology has set up several committees to coordinate a scientific response, following a request from Jack Gibbons, head of the White House Office of Science and Technology Policy. One committee, under the chairmanship of Stephen Ragone of the US Geological Survey, met last week to discuss research priorities.

The situation is a classic example of how science can serve -- or fail to serve government. Clinton recently went to $\mathrm{St}$ Louis, Missouri, to present $\$ 7$ billion of emergency aid to the populace, and that is million research money out of the flood", says Stakhiv. "Unless we get the agencies to agree on a programme, it'll be dispersed and there will be no integration. That is what all the various task forces are trying to deal with."

Flood management veterans say that the government has already been given advice on how to achieve such coordination, but has not taken it. Gilbert White, founder of the natural hazards research centre at the University of Colorado, says: "This gives the US the chance to take a fresh and bold look at what it's been doing. Instead of flood control we should be concerned with the wise use of flood plains, which may involve flood control." White wants the administration to implement the unheeded recommendation of a report, produced last year by an interagency task force, that the federal government should define good flood plain management, and set goals and a timetable for its implementation across the country.

In his drive for 'smaller' government, President Ronald Reagan disbanded the US Water Resources Council in 1982. Follow- ing the Mississippi floods, Clinton will probably restore some form of national coordination.

But the important decisions on the best response to the flood will be taken at a lower level, out of the public eye, and will be somewhat more sophisticated than the public battle between the Corps of Engineers and the green lobby would suggest.

Kevin Coyle of American Rivers sums up the green case when he says that "the whole idea of river engineering is flawed". But Coyle was stopped in his tracks when a journalist pointed out that 40 deaths, however regrettable, was a very small number for such an angry Mississippi to extract in a heavily populated area. "Without the levees, this disaster would have been worse", says Stakhiv "The levees gave people time. Nothing is perfect: all we can do is mitigate the worst of the hazards."

Engineers and scientists will now work to mitigate them further, with more support than they have had in the past and perhaps within an integrated framework decided by the federal government. "The effect of the floods is to draw attention to the situation", says White. "The precedent is that major policy changes in this country often come from an emergency."

Colin Macilwain

\section{Community values}

Munich. The European Commission is to organize a "week of science culture" in November to raise the profile of European science. The research commissioner, Antonio Ruberti, brought the idea with him from Italy where he was minister for research until last year. He introduced the annual Italian week of scientific culture in 1991.

The twenty-odd events will range from competitions to conferences and will be widely publicized. Participants are not confined to EC countries: several other West European countries are taking part. Organization of each national project will be shared with other European countries.

Most of the large international European laboratories are also taking part. The European Southern Observatory (ESO) at Garching in Germany, for example, will hold an essay competition on astronomy for high-school students in 17 European countries and also in Chile where it has a large observatory. The 18 winners will spend two weeks with ESO scientists working on genuine research projects, which will eventually be published. They will also spend three nights in Chile using ESO's most powerful telescopes.

Alison Abbott 